\title{
Electron-Microscopic Studies on Morphological Changes in the Surface Mucous Cell during Migration in the Stomach of the Golden Hamster*
}

\author{
Haruyuki Tatsumi, Tadanobu Ban and Hisao Fujita \\ Department of Anatomy (Prof. H. Fujita), Osaka University Medical School, Osaka, Japan
}

Received September 26, 1985

\begin{abstract}
Summary. Morphological changes in the surface mucous cells in the gastric body of the golden hamster occurring during their movement from the lower to the upper portion of the gastric pit have been observed by using scanning as well as transmission electron microscopes. The cells have a wide base and a narrow apex in the lower and middle portions of the pit, while at the opening of the pit to the gastric lumen, they become taller and funnellike in shape, and are characterized by well developed interdigitations and intermediate filaments sometimes associated with desmosomes. During this transformation of the cell contour, the nucleus moves towards the upper region of the cytoplasm, whereas the Golgi apparatus moves downwards to the infranuclear region. Then, there appear secondary lysosomes showing crinophagy and lipid droplets around or near the Golgi apparatus. Though the basal part of the cells is very small, no images of the detachment of the basal plasma membrane from the basal lamina could be seen even at the site of severe cell degeneration. The tall funnel-shaped cells showing these characteristics are located on the interfoveolar ridges of the underlying fibrous layer and line the free surface of the stomach. Therefore, the interfoveolar cells which have lost the activity of secretory granule production and are going to undergo physiological degeneration are thought to be highly differentiated elements as a covering epithelium to protect the underlying tissue, resembling in this respect the keratinocyte of the epidermis.
\end{abstract}

A simple columnar epithelium of the gastrointestinal tract belonging to "renewing cell population," is continuously produced in the generative cell zone, and then migrates mainly upwards to a destination where cell loss takes place (LEBLOND and WALKER, 1956; Messier and Leblond, 1960). During its migration, immature cells in the lower portion of the gastric pit and in the intestinal crypt differentiate to possess their own characteristic features. In the small intestine, the length of the microvilli of the absorptive cell and the specific enzyme activities in the plasma membrane and cytoplasm increase as the cell moves upwards along the villus (BROWN, 1962; WEISER, 1973; SHAKIR et al., 1977; BAylin et al., 1978). The fine structural aspects on the surface mucous cells of the stomach have been a subject of study for many researchers (KuRosumi et al., 1958; Helander, 1962, 1981; Ito and Winchester, 1963; Lillibridge, 1964; Rubin et al., 1968; Pfeiffer, 1970a, b), but there are some problems remaining to be solved regarding the morphological changes in the cells during migration.

*This study was supported by grants from the Ministry of Education, Science, and Culture, Japan. 
Attempts have been made to clarify the changes in the surface mucous cells during migration, as well as cell loss in fine structural and three dimensional aspects.

\section{MATERIALS AND METHODS}

Ten male golden hamsters weighing $60-100 \mathrm{~g}$ were used for this study. The animals, fasted for $24 \mathrm{hr}$, were anesthetized with sodium pentobarbital and perfused from the left ventricle with $3 \%$ glutaraldehyde solution buffered at pH 7.4 with $0.1 \mathrm{M}$ Millonig's phosphate. The upper part of the gastric body (great curvature) of the stomach was carefully removed, and cut into small pieces.

For transmission electron microscopy, the specimens were immersed in the same fixative for $2 \mathrm{hr}$ at $4{ }^{\circ} \mathrm{C}$ and postfixed with $1 \% \mathrm{OsO}_{4}$ solution for $1 \mathrm{hr}$ at $4^{\circ} \mathrm{C}$. The tissue blocks were rinsed with $10 \%$ sucrose solution and stained with $3 \%$ uranyl acetate aqueous solution for 1 hr at room temperature. They were dehydrated in graded concentrations of ethanol and embedded in Epon epoxy resin. Ultrathin sections, cut on a Porter-Blum ultramicrotome and stained doubly with uranyl acetate and lead citrate, were examined with Hitachi $\mathrm{H}$ 500 and JEM 1200EX electron microscopes.

For the histochemistry of acid phosphatase, stomachs perfused with $1.5 \%$ glutaraldehyde solution buffered at $\mathrm{pH} 7.4$ with $0.1 \mathrm{M}$ cacodylate buffer were sliced in the fixative using a vibratome at $40 \mu \mathrm{m}$ in thickness, and rinsed overnight in $0.1 \mathrm{M}$ cacodylate buffer containing $5 \%$ sucrose at $4 \%$. The specimens

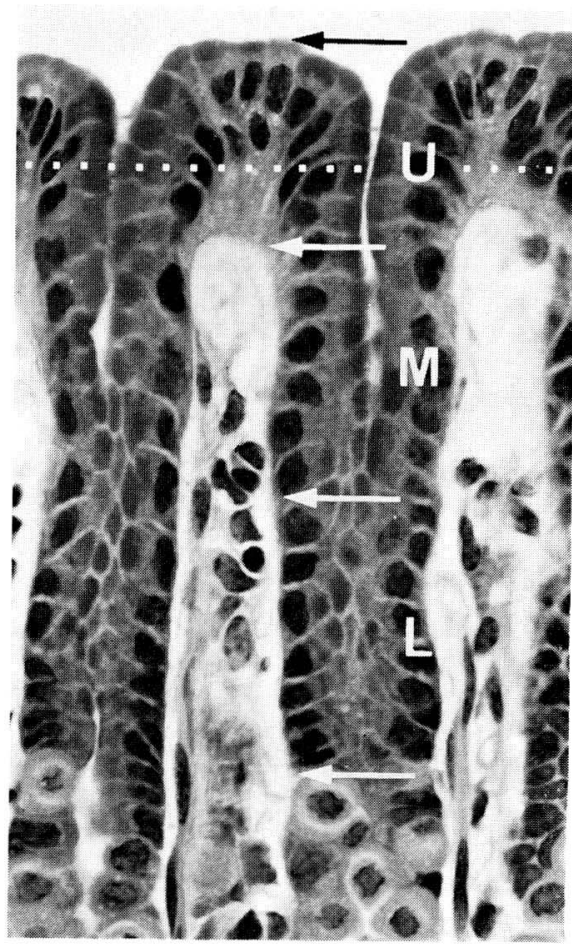

Fig. 1. Gastric pits and gastric glands of a golden hamster. Periodic acid-Schiff (PAS)hematoxylin staining. The gastric pit is subdivided into upper $(U)$, middle $(M)$ and lower $(L)$ portions. Dotted line indicates the level of the horizontal section of Figure $5 . \quad \times 500$ were incubated for $1 \mathrm{hr}$ at $37^{\circ} \mathrm{C}$ in a modified medium by Gomori (1952), consisting of $3 \% \mathrm{Na}-\beta$-glycerophosphate $10 \mathrm{ml}, 0.05 \mathrm{M}$ sodium

Fig. 2. Scanning electron micrographs of the stomach of a golden hamster. a, c, and d. Some surface mucous cells are removed mechanically from the underlying dense connective tissue layer, which is continuous downwards to the fibrous stromal sheaths encasing each gastric pit. The center of the interfoveolar fibrous layer (dense connective tissue layer) between the pits bulges towards the gastric lumen as a ridge (arrows). a. Inner surface of the longitudinally fractured stromal sheath $(S)$, after removing the gastric pit cells. $\times 1,000$. b. An apical surface of the covering mucous cells. In the center, the extrusion of the mucous granules by physiological degeneration of the cell can be seen. $\times 7,200$. c. A transitional portion from the middle to upper gastric pit. The cells at this portion are characterized by a narrow apex, wide base, and low height. Arrow: interfoveolar ridge $\times 2,300$. d. Tall funnel-shaped cells with well developed interdigitations at the interfoveolar ridge (arrows). The basal parts of the surface mucous cells facing the gastric lumen converge on the interfoveolar ridge. $\quad \times 2,100$ 
acetate buffer ( $\mathrm{pH} 5.0) 100 \mathrm{ml}$, saccharose $5.0 \mathrm{~g}, \mathrm{~Pb}\left(\mathrm{NO}_{3}\right)_{2} 0.12 \mathrm{~g}$. They were postfixed and processed for electron microscopy as described above.

For scanning electron microscopy, the tissue blocks fixed overnight with $3 \%$ glutaraldehyde solution mentioned above were placed in $8 \mathrm{~N} \mathrm{HCl}$ at $60^{\circ} \mathrm{C}$ for $30 \mathrm{~min}$ (UEHARA and Suyama, 1978). After being rinsed with distilled water, the blocks were postfixed



Fig. 2. Legend on the opposite page 
with $1 \% \mathrm{OsO}_{4}$ for $4 \mathrm{hr}$ and cracked in distilled water. They were treated with the tannin-osmium conduction staining method (Murakami et al., 1977), dehydrated with ethanol, immersed in isoamyl acetate and critical point-dried in liquid carbon dioxide. Specimens coated with platinum were examined with a Hitachi S-800 field-emission scanning electron microscope.

For light microscopy, the tissue blocks fixed overnight were dehydrated in ethanol and embedded in a plastic medium (Polysciences Inc.). Semithin sections ( $2 \mu \mathrm{m})$ were cut with a JB-4 microtome (Sorvall) and stained with periodic acid-Schiff (PAS)-hematoxylin.

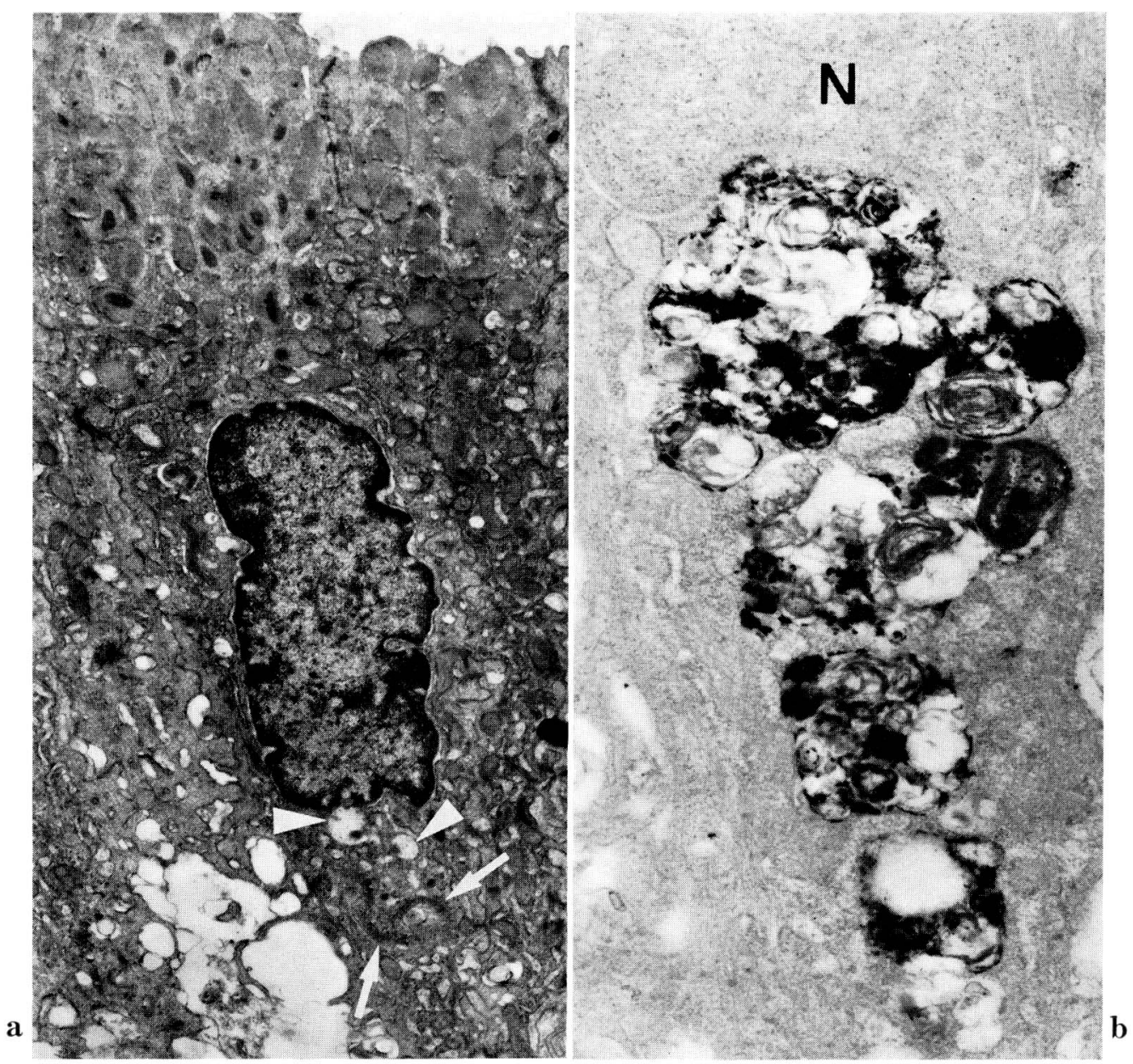

Fig. 3. a. A tall funnel-shaped cell at the interfoveolar ridge. Note the reversed localization of the nucleus (upper) and the Golgi apparatus (lower) (arrows). Immature secretory granules (arrow heads) are seen near the Golgi apparatus. $\times 9,000$. b. Demonstration of acid phosphatase activity in the funnel-shaped cell without counter staining. Large secondary lysosomes showing reaction products are situated under the nucleus $(N) . \quad \times 14,000$ 




Fig. 4. Golgi apparatus in the interfoveolar cell. a. Note immature secretory granules (S) with heterogeneously electron dense materials, secondary lysosomes $(L)$ and small vesicles around the circularly arranged Golgi apparatus. $\times 32,000$. b. Secondary lysosomes containing immature secretory granule $(S)$, rough endoplasmic reticulum (arrow) and myelinated structures. Note the bundles of intermediate filaments (arrow heads) running randomly in the cytoplasm. $\times 41,000$ 


\section{RESULTS}

For convenience in reference, the gastric pit is subdivided into three parts: the upper, middle and lower portions (Fig. 1). The surface mucous cells of the upper portion facing the lumen of the stomach are called covering mucous cells or interfoveolar cells.

At the lower and middle portions of the gastric pit, the cells are rectangular in shape in a longitudinal section along the gastric pit (Fig. 1), and are sectorial in a transverse one. As a whole, the cells have a narrow apex and a wide base, and are about $15-20 \mu \mathrm{m}$ in height. With periodic acid Schiff staining, it becomes clear that mucous granules, which are oblong in shape, $400 \times 800 \mathrm{~nm}$ in their long and short diameters, and packed together in the apical part of the cell, increase in number as the cell climbs up along the gastric pit. A few mucous granules can also be seen at the supranuclear region, corresponding to the area of the Golgi apparatus. A few immature granules occurring near the Golgi apparatus are round in shape and lower in electron density as compared with mature ones in the apical cytoplasm.

Specimens for scanning electron microscopy, in which some of the covering mucous cells facing the gastric lumen were mechanically removed from the underlying connective tissue, show the lateral surfaces of the covering cells and the underlying dense fibrous connective tissue layer (TAтsumi et al., 1985), which is continuous downwards to the stromal sheaths (HatTori, 1974) encasing each gastric pit (Fig. $2 \mathrm{a}, \mathrm{c}, \mathrm{d}$ ). On this

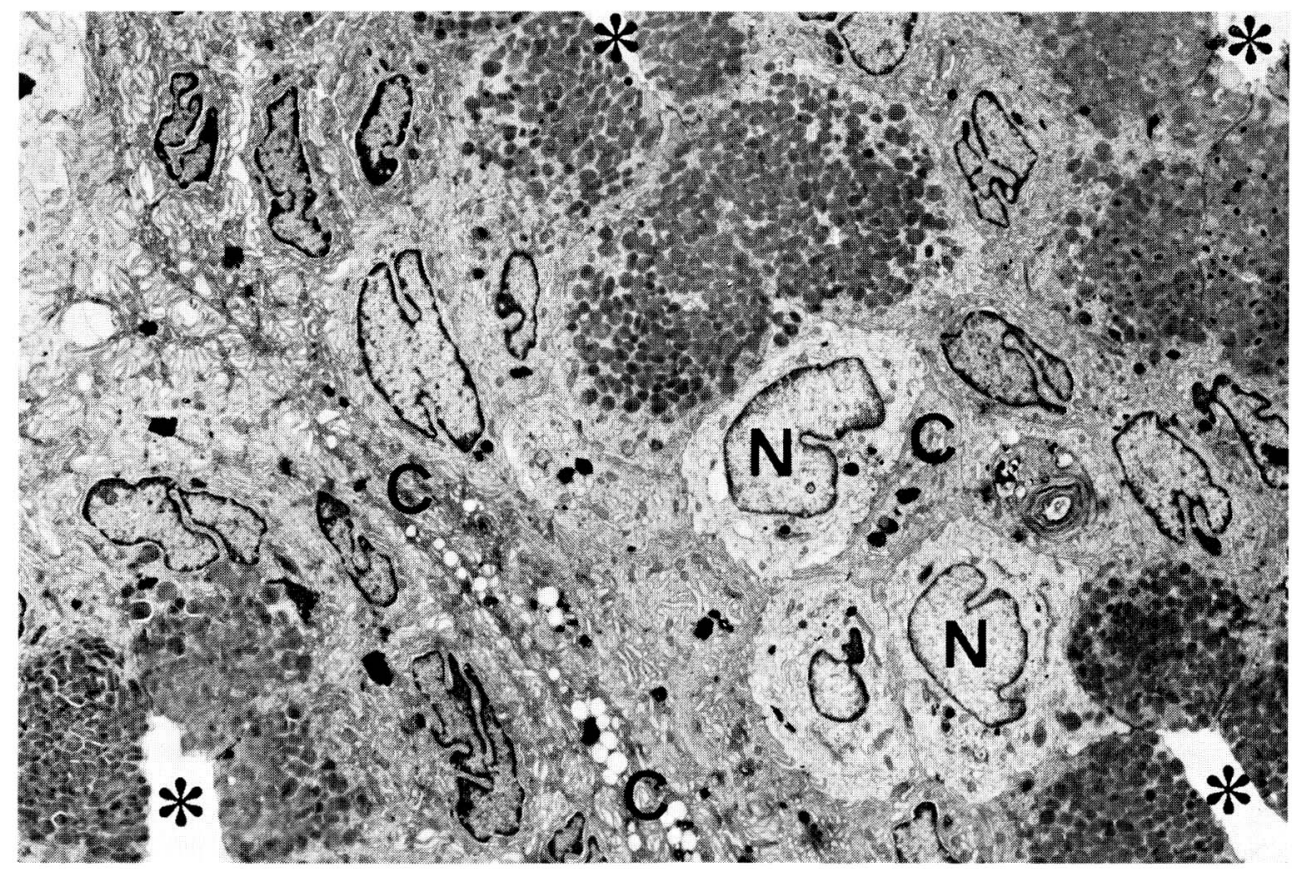

Fig. 5. Horizontal section of the gastric wall at the level as shown in Figure 1. a. Four gastric pits (asterisks) are seen in this section. Nearby the gastric pit apical parts of the surface mucous cells showing packed mucous granules, and nuclei $(N)$ of the degenerating surface mucous cells, showing lucent cytoplasm, are seen. In the middle area between two gastric pits, cross sections ( $C$ ) of the basal parts of the cells locating at the interfoveolar ridge are seen. They are extremely small in the cross section and stretch in the direction of the interfoveolar ridge. $\times 3,000$ 
fibrous layer are situated surface mucous cells with a basal lamina. The center of the interfoveolar fibrous layer between the pits bulges into the gastric lumen as a ridge (Fig. 2 a, c, d), and we call it an interfoveolar ridge of the fibrous tissue layer.

At the opening of the gastric pit to the lumen of the stomach, the surface mucous cells change in shape from possessing a narrow apex about $2 \times 5 \mu \mathrm{m}$ in diameter, a wide base $5 \times 13 \mu \mathrm{m}$ in diameter, and low height of $15-20 \mu \mathrm{m}$ (Fig. $2 \mathrm{c}$ ), to having a wide apex about $6 \times 9 \mu \mathrm{m}$ in diameter, a narrow base $1 \times 3 \mu \mathrm{m}$ in diameter, and tall height of 30 $40 \mu \mathrm{m}$, and finally to a slender funnel shape with well developed interdigitations at the interfoveolar ridge (Fig. 2d). The covering mucous cells making up the surface of the gastric wall and facing the gastric lumen have an extremely small basal part to their cytoplasm, which covers the interfoveolar ridge of the fibrous tissue layer (Fig. 2 a, c, d).

The transformation of the cell contour during the migration to the ridge is accompanied by changes in the cytoplasmic structure. The nucleus moves from the basal half of the cell to the apical one and becomes located just beneath the packed mucous granules, while the Golgi apparatus, some mucous granules and lysosomes are situated lateral to or under the nucleus (Fig. 3a). The cells, whose Golgi apparatus is localized under the nucleus, are typically funnel-shaped and located on the interfoveolar ridge (Fig. 3a, 4). Near the Golgi apparatus are some immature secretory granules containing heterogeneously electron dense materials, many small vesicles, about $50 \mathrm{~nm}$ in diameter, and some dense bodies, about $100 \mathrm{~nm}$ in diameter (Fig. 4). Furthermore, secondary lysosomes $0.4-2 \mu \mathrm{m}$ in diameter housing some vesicles, myelinated bodies

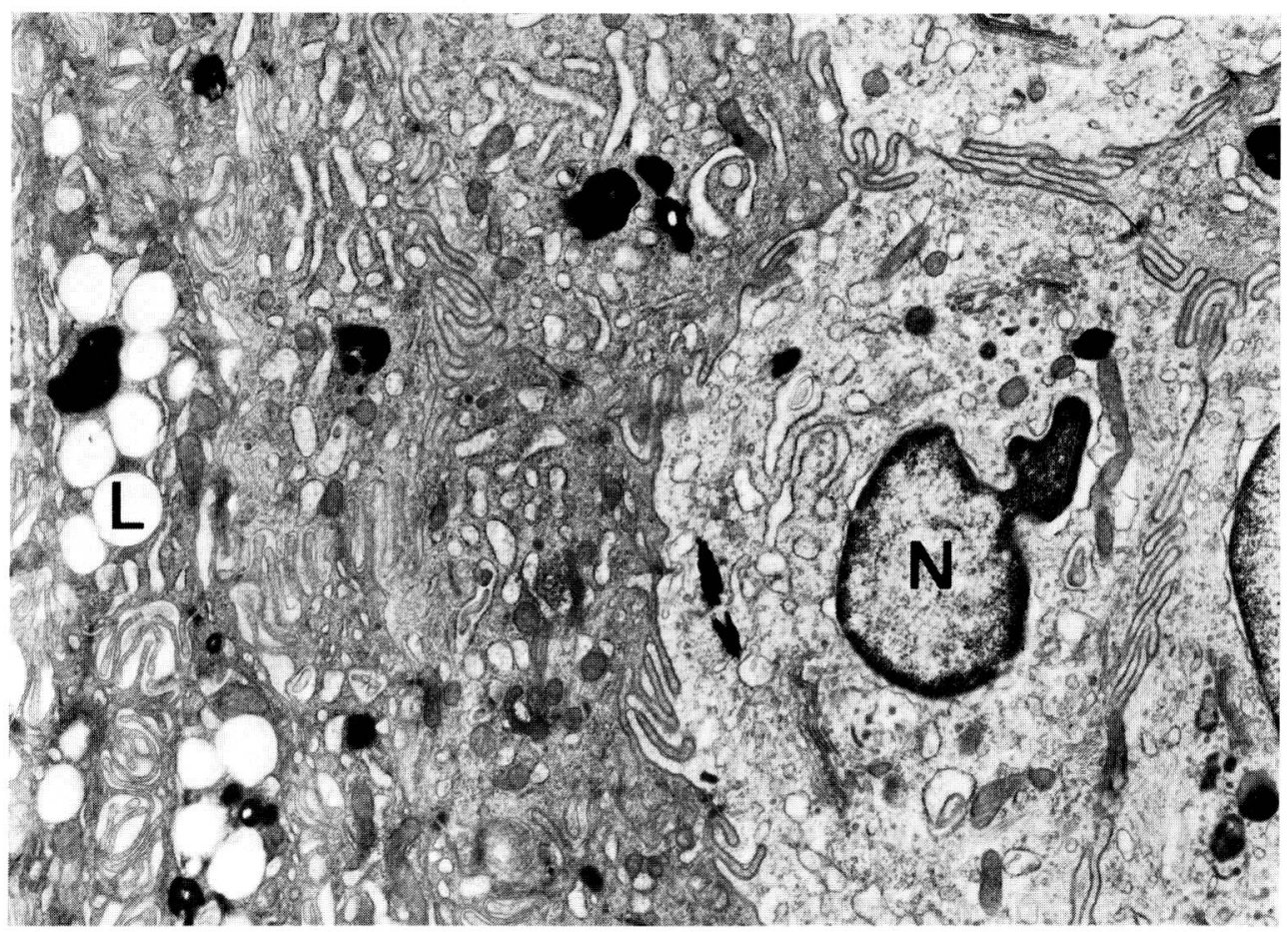

Fig. 5. b. Higher magnification of a part of Figure 5a. The Golgi apparatus, dilated cisternae of rough endoplasmic reticulum and lysosomes are located around the nucleus $(N)$. Parts of the cell cytoplasms (left), which are located on the interfoveolar ridge, are characterized by lipid droplets $(L)$, lysosomes, and irregular cell contours. $\quad \times 10,000$ 


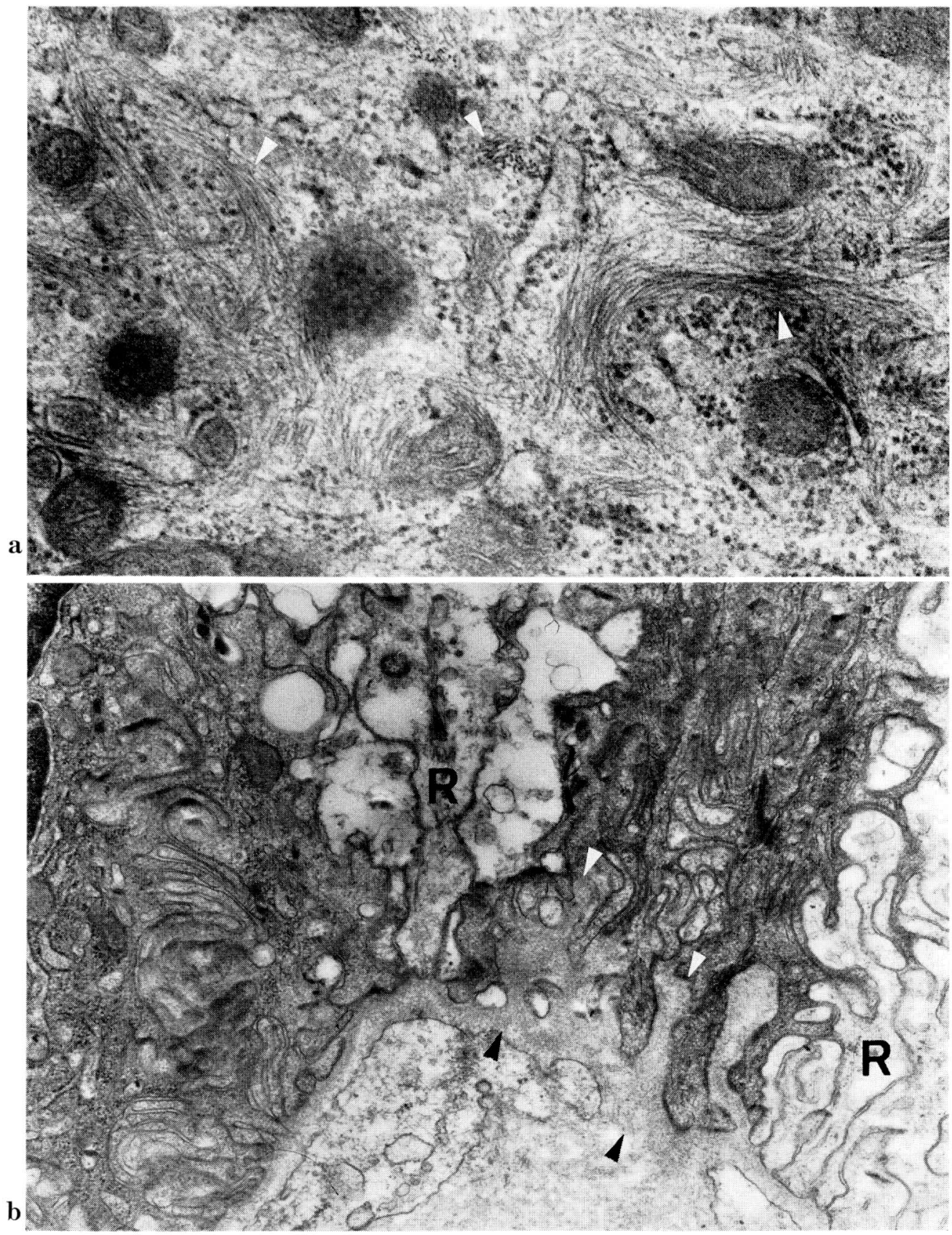

Fig. 6. a. Abundant intermediate filaments (arrow heads) in the cytoplasm of the interfoveolar cell. $\times 41,000$. b. A basal part of the cell showing strongly developed infoldings of the plasma membrane. The basal plasma membrane is not detached from the basal lamina (arrow heads) which is thickening at the interfoveolar ridge. In spite of the discharge of the contents of the cell to the gastric lumen, there still lie the basal and lateral plasma membranes of the ruptured cells $(R) . \quad \times 18,000$ 
and lipid droplets are often seen around the Golgi area. Occasionally the secondary lysosomes contain immature secretory granules, rough endoplasmic reticulum and ribosomes (Fig. 4b). These secondary lysosomes, showing the acid phosphatase activity, often develop in the tall funnel-shaped cells located on the interfoveolar ridge (Fig. $3 b)$.

In order to obtain more detailed information about the orientation of these cells, the horizontal section of the gastric wall is observed at the level indicated with a dotted line in Figure 1. In this section, some surface mucous cells show only packed mucous granules in their apical parts, while the adjacent cells show their nucleus to be located in the center of the cytoplasm (Fig. 5a). Still other cells show a small part of the nucleus, around which the Golgi apparatus, immature secretory granules and lysosomes can be noted (Fig. $5 \mathrm{~b}$ ). In the middle area between the gastric pits, the cross section of the basal part of the cell located at the interfoveolar ridge is seen. It is extremely small and irregular in outline, and stretches in the direction of the interfoveolar ridge, being characterized by dilated cisternae of rough endoplasmic reticulum, many lysosomes and lipid droplets, and sometimes by an electron-lucent cytoplasmic matrix (Fig. 5b). A low-electron dense cytoplasm is often observed in the funnel-shaped cell located in the middle area between the gastric pits in the cross section. In the cytoplasm of the interfoveolar cell, bundles of randomly running intermediate filaments are fairly well developed (Fig. 4b, 6a) as compared with those of the cell located in the lower gastric pit, and are sometimes associated with desmosomes.

In a few interfoveolar cells whose apical plasma membrane disappears by physiological degeneration, SEM is able to clearly reveal the contour of each granules of the mucous mass (Fig. 2b). In cells showing a disappearance of the apical plasma membrane and discharge of the intracellular contents, the basal and lateral plasma membranes are usually seen as a boundary between the gastric lumen and the underlying connective tissue by transmission electron microscopy (Fig. 6b). Irrespective of the discharge of the cytoplasmic contents, the basal plasma membrane usually accompany the basal lamina, though the basal part of the cell located on the basal lamina could be extremely small in length (Fig. 6b). At this position, complicated wavy basal infoldings and the thickened basal lamina are characteristic. Under the basal lamina are abundant collagen fibrils and fibroblasts.

\section{DISCUSSION}

This study clearly demonstrated that the surface mucous cells undergo marked changes in their shape and structure at the later stage of their migration to the surface of the gastric wall. The transformation of the cell shape from that of a narrow apex, wide base and short height to one with a wide apex, narrow base and tall height is highly impressive. These phenomena seem to be correlated with the dislocation and structural change of the intracellular elements.

The locational relationships of the nucleus, the Golgi apparatus and the basal lamina are important for deciding the cell polarity, which is known to indicate the direction of the secretion in exocrine cells, and of absorption in intestinal cells. Therefore the surface mucous cells on the interfoveolar ridge showing a reversed relationship in localization between the nucleus and the Golgi apparatus, and the reduction of the contact area between the basal plasma membrane and the basal lamina could be regarded as having lost their complete polarity. 




Fig. 7. Schematic drawing of changes of surface mucous cells during migration from the middle to the upper gastric pit. Note the changes in cell contour and the cytoplasmic structures. Short arrow: interfoveolar ridge, $C$ blood capillary, $P$ gastric pit, $S$ stromal sheath. 
Though Golgi (1909) described the dislocation of the Golgi apparatus in the surface mucous epithelium of the stomach, which was cofirmed by several researchers (Bowen, 1923; HibBard, 1942; Tatsumi et al., 1985), the fine structural aspects of this phenomenon have not yet been sufficiently observed. Electron microscopy reveals, near the descending Golgi apparatus, many vesicles, secondary lysosomes, and unusual immature secretory granules with heterogeneously electron dense materials. The autolysosomes containing secretory granules could be in a process of crinophagy to dispose of secretory granules in the interfoveolar cell. Similar findings have been reported in the mammotrophs of the anterior pituitary gland at the postlactating period (SMITH and FARQUHAR, 1966). These observations such as the dislocation of the organelles and crinophagy suggest that the production and transportation of the secretory granules are disordered and the lysosomes dispose of the immature secretory granules in the funnel-shaped cells.

The interfoveolar cells often have a few lipid droplets in the subnuclear region, which are thought to be in the last stage of the secondary lysosome ( FARQUHAR, 1966). From the fact that almost all the surface of the gastric wall consists of the slender funnel-shaped cells and only a few of them show the loss of the apical plasma membrane, we consider that the cells showing these changes might remain for a time after they undergo dysfunction in secretory granule production.

Intermediate filaments are thought to have an important role in the mechanical integration of various cytoplasmic organelles (SUN et al., 1979; LAzARIDEs, 1980), and the surface mucous cells in the rat have been described as containing an abundant prekeratin-like material (DABIKÉ and KoENIG, 1983). From our observation, the intermediate filaments are fairly well developed in the interfoveolar cells as compared with those in the cells located in the lower gastric pit. In addition, the cells at the interfoveolar ridge are much taller and have well developed interdigitations. These characteristic structures would serve as a shock absorber to disperse the mechanical force generated by the peristalsis or food contact into adjacent cells in order to keep the epithelial integrity. As the basal part of the interfoveolar cells, which has the likelihood of rupturing the apical plasma membrane, is so small, and the basal plasma membrane remains, the cell defect may be replenished immediately with the surrounding cells at the time of cell loss, without any opening of the underlying connective tissue to the gastric lumen. Therefore, in the course of climbing up along the gastric pit, the cells are thought to become more efficient for protection of the tissue.

The narrowness of the basal part of the cell, which is in contact with the basal lamina, may be due to the partial detachment of the basal plasma membrane from the basal lamina, though a complete detachment could not be observed. At this position the development of the basal infoldings and the thickening of the underlying basal lamina may play a role in preventing the cell from detaching.

The transformation of the cell contour during migration seems to result in the cytoplasmic changes, having not only a negative phase in a secretory function but also a positive phase in terms of protective mechanisms. In this sense, the interfoveolar cells, which have lost the activity of the secretory granule production and are soon going to undergo physiological degeneration, are thought to be highly differentiated elements of a covering epithelium to protect the underlying tissue, resembling in this respect the keratinocytes of the epidermis.

The changes described above are summarized in a diagram (Fig. 7). 


\section{REFERENCES}

Baylin, S. B., S. A. Stevens and K. M. M. Shakir: Association of diamine oxidase and ornithine decarboxylase with maturing cells in rapidly proliferating epithelium. Biochim. biophys. Acta 541: 415-419 (1978).

Bowen, R. H. :Studies on the Golgi apparatus in gland-cells. I. Glands associated with the alimentary tract. Quart. J. microsc. Sci. 70: 75-112 (1926).

Brown, A. L.: Microvilli of the human jejunal epithelial cell. J. Cell Biol. 12: 623-627 (1962).

Dabiké, M. and C. S. Koenig : Intermediate filaments of the cytoskeleton in glandular cells of the rat fundic mucosa: Immunofluorescence and electron microscopy study. Anat. Rec. 207: 297308 (1983).

Golgi, C.: Sur une fine particularité de structure de l'épithélium de la muqueuse gastrique et intestinale de quelques vertébrés. Arch. Ital. Biol. 51: 213-245 (1909).

Gomori, G.: Microscopic histochemistry III. The University of Chicago Press, Chicago, 1952 (p. 193).

Hattori, T.: On cell proliferation and differentiation of the fundic mucosa of the golden hamster: Fractographic study combined with microscopy and ${ }^{3} \mathrm{H}$-thymidine autoradiography. Cell Tiss. Res. 148: 213-226 (1974).

Helander, H. F.: Ultrastructure of fundus glands of the mouse gastric mucosa. J. Ultrastr. Res. Suppl. 4: 1-123 (1962).

- The cells of the gastric mucosa. Int. Rev. Cytol. 70: 217-289 (1981).

Hibbard, H.: The "Golgi apparatus" during development in the stomach of gallus domesticus. J. Morphol. 70: 121-149 (1942).

Ito, S. and R. J. Winchester: The fine structure of the gastric mucosa in the bat. J. Cell Biol. 16: 541-577 (1963).

Kurosumi, K., S. Shibasaki and G. Uchida : Electron microscope studies on the gastric mucosa of normal rats. Arch. histol. jap. 15: 587-624 (1958).

Lazarides, E.: Intermediate filaments as mechanical integrators of cellular space. Nature 283: 249-256 (1980).

Leblond, C. P. and B. E. Walker : Renewal of cell populations. Physiol. Rev. 36: 255-276 (1956).

Lillibridge, C. B.: The fine structure of normal human gastric mucosa. Gastroenterology 47: 269-290 (1964).

Messier, B. and C. P. Leblond: Cell proliferation and migration as revealed by radioautography after injection of thymidine- $\mathrm{H}^{3}$ into male rats and mice. Amer. J. Anat. 106: 247-285 (1960).

Murakami, T., K. Yamamoto and T. Itoshima: Modified tannin-osmium conductive staining method for non-coated scanning electron microscope specimens: Its application to microdissection scanning electron microscopy of the spleen. Arch. histol. jap. 40: 35-40 (1977).

Pfeiffer, C. J.: Gastric surface morphology in man, monkey, and ferret: Evidence for in situ surface cell degeneration. Exp. mol. Pathol. 13: 319-328 (1970a).

: Surface topology of the stomach in man and the laboratory ferret. J. Ultrastr. Res. 33: 252-262 (1970b).

Rubin, W., L. L. Ross, M. H. Sleisenger and M. B. Jeffries: The normal human gastric epithelia: A fine structural study. Lab. Invest. 19: 598-626 (1968).

Shakir, K. M. M., S. Margolis and S. B. Baylin: Localization of histaminase (diamine oxidase) in rat small intestinal mucosa: Site of release by heparin. Biochem. Pharmacol. 26: 2343-2347 (1977).

Smith, R. E. and M. G. Farquhar: Lysosome function in the regulation of the secretory process in cells of the anterior pituitary gland. J. Cell Biol. 31: 319-347 (1966).

Sun, T. T., C. Shih and H. Green: Keratin cytoskeletons in epithelial cells of internal organs. Proc. Nat. Acad. Sci. U.S.A. 76: 2813-2917 (1979).

Tatsumi, H., H. Fujita and S. Tamura: Electron-microscopic studies on the physiological cell loss in the gastric mucosa of the golden hamster. Cell Tiss. Res. 239: 343-347 (1985).

Uehara, Y. and K. Suyama : Visualization of the adventitial aspect of the vascular smooth muscle cells under the scanning electron microscope. J. Electron Microsc. 27 : 157-159 (1978). 
Weiser, M. M. : Intestinal epithelial cell surface membrane glycoprotein synthesis. I. An indicator of cellular differentiation. J. biol. Chem. 248: 2536-2541 (1973).

藤田尚男

产530 大阪市北区中之島

大阪大学医学部

解剖学教室
Prof. Hisao Fujita

Department of Anatomy

Osaka University Medical School

4-3-57 Nakanoshima, Kitaku

Osaka, 530 Japan 